УДК 004.738.5:339

(C) 2013

Тягунова Н. М., кандидат економічних наук, Гудзенко М. Ю., аспірант *

ВНЗ Укоопспілки «Полтавський університет економіки і торгівлі»

\title{
ІНТЕРНЕТ-ТОРГІВЛЯ: СУТНІСТЬ ТА ОСОБЛИВОСТІ
}

\section{Рецензент - доктор економічних наук М. В. Макарова}

Узагальнено і систематизовано підходи вітчизняних та зарубіжних науковців щзодо визначення сутності понять «електронна комериія» та «Інтернет-комериія». Запропоновано визначення поняття «Інтернет-торгівля» на основі аналізу основних складових торговельної діяльності, щчо здійснюється за допомогою телекомунікаційних можливостей всесвітньої мережі: Інтернет-

торгівля - ие така форма торгівлі, за якої вся діяльність, пов'язана з купівлею-продажем товарів, ведеться через Інтернет. При иьому внутрішні проиеси, пов'язані з організацією торговельної діяльності, можуть бути реалізовані різними електронними методами.

Ключові слова: електронна комериія, Інтернет-торгівля, електронна торгівля, комериійна діяльність, телекомунікаційні технології, Інтернет.

Постановка проблеми. Швидкий розвиток інформаційних технологій та впровадження їх в усі сфери бізнесу зумовлює необхідність формування понятійного апарату електронної комерції, поскільки досить часто зустрічається плутанина в досить схожих на перший погляд поняттях електронної й Інтернет-комерції та електронної й Інтернет-торгівлі.

Аналіз останніх досліджень i публікацій, у яких започатковано розв'язання проблеми. Дослідженнями щодо визначення сутності понять в електронній комерції займалися такі автори, як В. Звасс, А. Саммер, Г. Дункан, Д. Козьє, В. Тріз, Л. Стюарт, а також вітчизняні, зокрема, В. Л. Плескач, Т. Г. Затонацька, Н. Соловенко, В. В. Царев, А. О. Кантарович, В.В.Апопій, I. П. Міщук, В. О. Соболєв, М. В. Макарова та інші.

Мета і завдання дослідження. Метою даної статті $\epsilon$ визначення наукового поняття «ІІтернет-торгівля» та іï предметної області.

Завданням є висвітлення результатів досліджень понятійного апарату «електронної комерції».

Матеріалами досліджень $\epsilon$ наукові праці зарубіжних та вітчизняних науковців, а також нормативні документи.

Методами досліджень $\epsilon$ узагальнення та систематизація, аналіз і синтез.

Результати дослідження. 3 кінця минулого сторіччя у світовій економіці завдяки швидкому розвитку інформаційних технологій відбулися значні зміни. Зростаюча конкуренція спонукає виробничі підприємства використовувати і вдосконалювати існуючі інформаційні системи та створювати нові. Відсутність діяльності будьякого характеру у всесвітній мережі для підприємства нині розцінюється як недолік. Брак часу у споживачів змушує все більше придбань робити через Інтернет, а це, в свою чергу, зумовлює ще більший розвиток електронної торгівлі завдяки появі нових іiі різновидів. Незважаючи на це, наукова спільнота ще не має не лише чіткого визначання поняття «Інтернет-торгівлі», а й ї̈ класифікації (ієрархічної структури).

Для того, щоб дати наукове визначення поняття «Інтернет-торгівлі», необхідно з'ясувати, чи тотожні поняття «електронна торгівля» та «Інтернет-торгівля», та чи можна відокремлювати їх від поняття «електронної комерції».

У переважній більшості зарубіжні автори, пояснюючи поняття електронної комерції, узагальнюють эї як таку діяльність, що охоплює всі типи електронних транзакцій між організаціями та зацікавленими особами [11].

Американський дослідник російського походження В. Звасс дає такі характеристики електронній комерції (Е-комерції): обмін бізнесінформацією, налагодження бізнес-відносин, здійснення бізнес-транзакцій через телекомунікаційні мережі, а також торгові відносини. Тобто він акцентує увагу саме на бізнесовій стороні поняття [13]. Такої ж думки дотримуються й А. Саммер та Г. Дункан, які визначають електронну комерцію як будь-яку форму бізнеспроцесу, в якому взаємодія між суб'єктами відбувається електронним чином [5].

* Науковий керівник - кандидат економічних наук Н. М. Тягунова 
Акцент на торгівлю у своїх працях робить Девід Козьє, вважаючи, що «...електронна комерція починалася 3 операцій купівлі-продажу та перерахування грошових засобів із допомогою комп'ютерних мереж, але сьогодні це поняття суттєво розширилося і включає торгівлю принципово новими видами товарів, наприклад, інформацією в електронному вигляді» [2].

Бізнесову і торгову сторони Е-комерції описують В. Тріз та Л. Стюарт, зокрема те, що вона включає застосування технологій у фінансовому бізнесі, електронному резервуванні квитків, постачанні, замовленнях, а також використання Інтернету для покупок і продажів товарів та послуг, включаючи післяпродажні послуги й підтримку [12]. Схоже визначення знаходимо і в працях таких вітчизняних науковців як В. Л. Плескач та Т. Г. Затонацька [4].

Поняття електронної комерції, що його пропонує Н. Соловенко, - це будь-який вид ділових операцій і угод, що передбачає використання передових інформаційних технологій та комунікаційних засобів із метою забезпечення більш високої економічної ефективності порівняно 3 традиційними видами комерції [7]. 3 нашого погляду, таке визначення не досить чітке, тому що вираз «передових інформаційних технологій та комунікаційних засобів» досить обтічно передає сутність цього поняття, поскільки автор не враховує фактора часу щодо функціонування та розвитку зазначених управлінських інструментів.

У підручнику «Електронна комерція» авторів В. В. Царева та А. О. Кантарович вказано наступне визначення поняття електронної комерції: «Це загальна концепція, що включає в себе будь-які форми ділових операцій, які здійснюються електронним способом і використовують різноманітні телекомунікаційні технології» [9]. Аналогічної думки дотримується й О. В. Юрасов, стверджуючи, що електронна комерція об'єднує використання в комерційній діяльності широкого спектру комунікаційних технологій, таких як електронна пошта, факс, електронний обмін даними EDI та електронні платежі EFT, Інтернет, інтранет, екстранет та ін. Автор відзначає, що поняття «електронна комерція» ширше, ніж «Інтернет-комерція», поскільки в нього входять усі види комерційної діяльності, що здійснюються електронним шляхом. Інтернет комерція, на його думку, - «це різновид електронної комерції, обмежений використанням лише мережі Інтернет» [10]. Таке визначення поняття «Інтернеткомерції» розділяють і В. В. Царевта А. О. Кантарович [9].
Таким чином, більшість вказаних вище науковців не роблять чіткого розмежування «електронної комерції» та «Інтернет-комерції». Схожу ситуацію спостерігаємо і 3 поняттями «електронна торгівля» та «Інтернет-торгівля».

У типовому законі про електронну торгівлю, прийнятому Комісією Організації Об'єднаних Націй із права міжнародної торгівлі, затвердженого резолюцією Генеральної Асамблеї ООН №51/162 від 16 грудня 1996 року, зазначається, що «всі угоди, які укладені за допомогою електронного обміну даними та інших засобів передачі даних, називаються «електронною торгівлею», які передбачають використання альтернативних паперовим методам передачі даних і зберігання інформації» [8] .

У згаданому вище підручнику В. В. Царева та А. О. Кантарович знаходимо наступне визначення: «електронна торгівля» - це процес купівліпродажу товарів та послуг, в якому весь цикл комерційної транзакції або ії частина відбувається електронним способом [9].

Більш чіткі у своєму трактуванні даного поняття автори В. В. Апопій, I. П. Міщук та ін. В їх розумінні електронна роздрібна торгівля охоплює не весь процес товарно-грошового обміну, а тільки ту частину, що безпосередньо пов'язана з купівлею-продажем [1].

Дослідник В. О. Соболєв у статті «Сутність основних понять Інтернет-торгівлі» пропонує наступне визначення: «Інтернет-торгівля - це організація i технологія процесу купівліпродажу товарів, в якому весь цикл комерційної транзакції або іiі частина відбувається електронним способом із використанням телекомунікаційних мереж та електронних фінансово економічних інструментів за допомогою реклами й розповсюдження товарів і послуг у мережі Інтернет» [6]. Таке визначення, на нашу думку, більше підходить до поняття «Інтернеткомерції», так як маркетинг не можна вважати частиною торгівлі.

Найбільш конкретне визначення Інтернетторгівлі дає М. В. Макарова: «Інтернет-торгівля це форма здійснення торгівлі товарами чи послугами з використанням технічних і програмних можливостей глобальної комп'ютерної мережі Інтернет». Вважаємо, що за рахунок інструментарію, вказаного у визначенні, його також можна віднести до Інтернет-комерції [3].

Висновок. Вважаємо, визначення поняття, що найповніше характеризує Інтернет-торгівлю, $\epsilon$ наступне: Інтернет-торгівля - це така форма торгівлі, за якої вся діяльність, пов'язана 3 купів- 
лею-продажем товарів, ведеться через мережу Інтернет. При цьому внутрішні процеси, пов'язані з організацією торговельної діяльності,

\section{БІБЛІОГРАФІЯ}

1. Апопій В. В., Міщук I. П., Ребицький В. М. [ma iн.] Організація торгівлі: підручник / I. П. Міщук, В. М. Ребицький [та ін.] ; За ред. В. В. Апопія. - 2-ге вид. - К.: ЦНЛ, 2005. - 615 с. 2. Козье Д. Электронная коммерция. - М. : Издательско-торговый дом «Русская редакция», 1999. -288 c.

3. Макарова М. В. Електронна комерція. - К. : Видавничий центр «Академія», 2002. -272 с.

4. Плескач В. Л., Затонацька Т. Г. Електронна комерція : Підручник. - К.: Знання, 2007. -535 с. 5. Саммер А., Дункан Гр. Маркетинг. Пятая волна. E-commerce. - M.: 1999. - 152 c.

6. Соболєв В. О. Сутність основних понять Інтернет-торгівлі [Електронний ресурс]. Режим доступу: http:/www.rusnauka.com/15_DNI_2008/ Economics/33645.doc.htm

7. Соловенко Н. Компьютерные сделки и электронный оборот юридических документов // Компьюномика. - Т. 1. - 1998. - №5. - 75 с. можуть бути реалізовані різними електронними методами.

8. Типовий закон про електронну торгівлю, прийнятий Комісією Організації Об'єднаних Націй iз права міжнародної торгівлі, затверджений резолюцією Генеральної Асамблеї ООН №51/162 від 16 грудня 1996 року.

9. Царев В. В., Кантарович А. А. Электронная коммерция: учебник для вузов. - С.-Пб. : Издательский дом «Питер», 2002. -320 с.

10. Юрасов А. В. Основы электронной коммерции. - М. : Горячая Линия - Телеком, 2008. $480 \mathrm{c}$.

11. Chaffey D. E-business and E-commerce Management. Strategy, Implementation and Practice. Prentice Hall, 2009. - 800 p.

12. Treese C. Winfield, Stewart Lawrence C. Designing Systems for Internet Commerce. - AddisonWesley, 1998. - $375 \mathrm{p}$.

13. Zwass $V$. Electronic Commerce: Structures and Issues // International Journal of Electronic Commerce. - V.1, №1, Fall, 1996. - P. 3-23. 